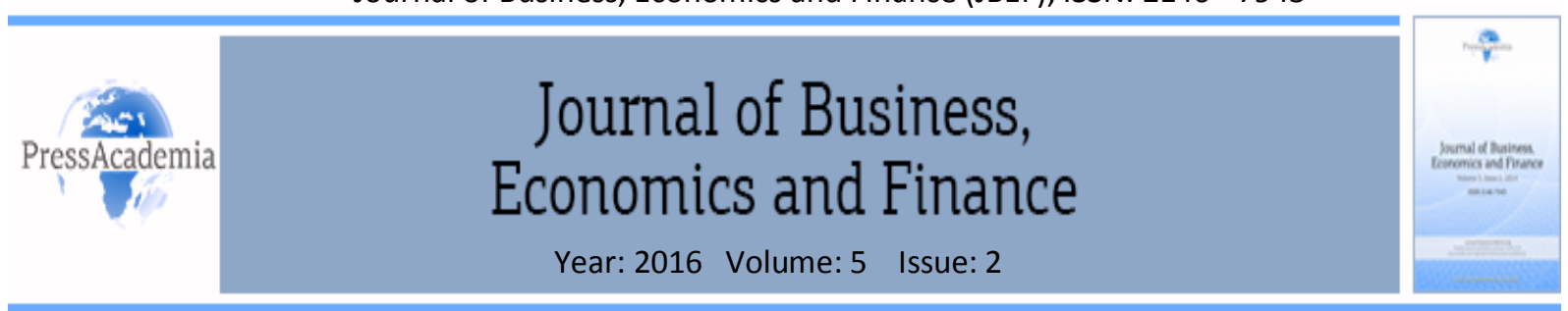

\title{
AN ANALYSIS ON THE EFFICIENCY OF BANK LENDING CHANNEL IN TURKEY*
}

\section{DOI: 10.17261/Pressacademia.2016219262}

\author{
Nilgun Caglarirmak Uslu ${ }^{1}$, Pinar Karahan ${ }^{2}$ \\ ${ }^{1}$ Anadolu University .ncaglarirmak@anadolu.edu.tr \\ ${ }^{2}$ Anadolu University. pkarahan@anadolu.edu.tr
}

\begin{abstract}
The aim of our study forms bank lending channel which defines the impacts of monetary policy on real economic activities by chancing loan supply of the banks. Changing loan supply by banks as a response to monetary shocks affects the accessibility of firms and household to the bank credit and this brings to important macroeconomic conclusions. In this study we conclude that Turkey's economy largely provided the conditions for the efficiency of bank lending channel. In the analysis of monthly data within the period 2002:1-2014:12 was used VAR model. The empirical results of the study show that monetary policy through the bank lending channel play an important role on the real economy in the short term. In this study it is confirmed that functioning of a bank lending channel for Turkey's economy.
\end{abstract}

Keywords: Monetary policy, monetary transmission mechanism, bank lending channel, VAR model.

JEL Classification: E52, E51, E44, C32.

\section{INTRODUCTION}

The discussions about the monetary transmission channels, through which monetary policy affects the real economy, are generally around the interest rate/money channel and credit channel. In interest rate channel which is based on the standard IS-LM model, it is assumed that non-monetary financial assets are perfect substitutes for each other. With the assumption that there is no financial market flaws; household, firms and banks are indifferent either bank loan or bond as representation of non-monetary financial assets. The fact that interest rate channel fails to takes the function of the banks to create loan into consideration caused the point of origin for credit channel which emphasizes the market flaws in the monetary transmission mechanism.

Bernanke and Blinder (1988) added a single assumption to the conventional IS-LM model. They assumed that besides "money" and "bonds" which appear in the money channel, there is a third asset called "bank loans" that is imperfectly substitutable with the other two assets (Bernanke, 1993). The point of departure of the credit view is the rejection of the assumption that bonds and bank loans are perfect substitutes. Based on the assumption of informational imperfections in financial markets, the credit channel assigns an active role to the supply of bank loans (Benkovskis, 2008).

Bank lending channel is the channel through which monetary policy actions are transferred into real economic activities over loan supply. Two conditions must be satisfied for bank lending channel to operate: (Cecchetti, 1995; Kashyap and Stein, 1994; Kashyap, Stein and Wilcox, 1992; Juks, 2004; Thornton, 1994; Jimborean, 2009; Inan, 2001; Oliner and Rudebusch, 1995; Oliner and Rudebusch, 1996b):

\footnotetext{
*This study is based on the unpublished PhD thesis which is called "The Real Effects of Monetary Policy through the Bank Lending Channel and Pass-Through of Monetary Policy to Loan Rates: The Case of Turkey" in Anadolu University.
} 
1. Monetary policy must affect banks' credit supply. When central banks conduct an open market sale to dampen aggregate demand drains bank reserves from the system. Reducing of bank reserves causes bank liabilities (deposits) to reduce, it must also reduce bank assets. Assuming that banks treat the loans and securities that make up their portfolios as imperfect substitutes, the loss of deposits will induce them to try to reduce both categories of assets (Bernanke, 1993). Therefore, loans and securities have to be imperfect substitutes in banks' balance sheets so that monetary policies may affect banks' loan supply.

2. There must be borrowers depending on bank loans. Banks play a special role in the financial system, because they are exceptionally appropriate to overcome informational problems in the credit market. Due to this special role of the banks, some borrowers will not be able to reach credit markets unless they receive loan from the banks (Mishkin, 2010). Therefore, the reduction of credit volume created by banking system has to have significant macroeconomic results (Bernanke, 1993; Claus and Grimes, 2003). In order for this condition to be hold, there must not be a relation of perfect substitutes between bank loan and other financing means in firms' balance sheets. In other words, firms should not be indifferent between issuing securities and receiving loans to finance their investment project. The amount of external funds in the financial structure of firms and the share of bank loans in the overall external financing determines the importance of banks loans for firms (Juks, 2004). The amount of bank dependent borrowers is associated with the development level of financial markets of the countries. Namely, the countries where capital markets are less developed and the direct access to these markets is poor have more bank dependent borrowers (Cecchetti, 1999). An important result that can be obtained from credit view is that the monetary policy has a larger effect on the expenditures of small firms which are more bank dependent, rather than the expenditures of large firms which can directly access to capital markets (Mishkin, 2010).

Contractionary monetary policy, which decreases bank reserves and bank deposits, decreases the quantity of bank loans available. Due to the fact that most borrowers depend on bank loans in order to finance their activities, the fall in loans decreases the expenditures for investment (and possibly, the consumption). Schematically, the effect of monetary policy may be demonstrated as below (Mishkin, 2010): Contractionary monetary policy $\rightarrow$ bank deposits $\downarrow \rightarrow$ bank loans $\downarrow \rightarrow$ total expenditures $\downarrow \rightarrow$ total output $\downarrow$

\section{EVALUATION OF EFFICIENCY CONDITIONS OF CREDIT CHANNELS FOR TURKISH ECONOMY}

Analyzing the existence of mentioned conditions for Turkish economy is important for both determining the main features of the banking system in Turkey and forming basis for empirical analysis of bank lending channel.

The position of banking sector in financial market has great importance on monetary policy actions creating real effects through banks' loan supply. The fact that banks have a great share in financial sector, along with central bank changing banks' loan supply, enable it to have an effect on total expenditures. By 2014, banks compose $86 \%$ of size of assets of financial sector in Turkey. The banking sector compose 1.994 .159 million TL of total size of assets of financial sector, which is 2.330 .923 million TL. (BAT, 2015). In this context, it is possible to say that banks, as a dominant factor in the sector, affect total credit volume to a great extent.

The response of banking system to a need of liquidity, emerging at the instant, though using what assets is very important for the credit channel to function (Inan, 2001). In this regard, the structure of size of assets of the banking sector, along with the share of banks in financial system, is very essential for the central bank to affect banks' loan supply.

As mentioned above, it is necessary that credit item in banks' balance sheets needs to be affected in accordance with monetary policy actions in order for bank credit channel to operate properly. In other words, banks must act by reducing their loans rather than reducing liquid assets and securities, as a response to decreasing deposits upon a tightening of monetary policy. Loans need to be high in asset items and low in securities so that loans and securities in banks' balance sheets can be imperfect substitutes. 
Table 1: Development and Structure of Assets in Turkish Banking (Percentage)

\begin{tabular}{|c|c|c|c|c|}
\hline Years & Liquid Assets & Financial Assets & Loans & Other * \\
\hline $\mathbf{2 0 0 2}$ & 16 & 40 & 27 & 17 \\
\hline $\mathbf{2 0 0 3}$ & 15 & 43 & 28 & 14 \\
\hline $\mathbf{2 0 0 4}$ & 14 & 40 & 34 & 12 \\
\hline $\mathbf{2 0 0 5}$ & 16 & 36 & 39 & 9 \\
\hline $\mathbf{2 0 0 6}$ & 15 & 35 & 45 & 5 \\
\hline $\mathbf{2 0 0 7}$ & 13 & 31 & 50 & 6 \\
\hline $\mathbf{2 0 0 8}$ & 14 & 29 & 52 & 5 \\
\hline $\mathbf{2 0 0 9}$ & 13 & 35 & 48 & 4 \\
\hline $\mathbf{2 0 1 0}$ & 10 & 30 & 52 & 8 \\
\hline $\mathbf{2 0 1 1}$ & 12 & 24 & 56 & 7 \\
\hline $\mathbf{2 0 1 2}$ & 14 & 21 & 58 & 7 \\
\hline $\mathbf{2 0 1 3}$ & 15 & 17 & 61 & 7 \\
\hline $\mathbf{2 0 1 4}$ & 14 & 16 & 63 & \\
\hline
\end{tabular}

* Fixed Assets, Rediscounts and Other Assets.

Source: The Banks Association of Turkey.

The development and structure of assets in Turkish banking sector between 2002-2014 are demonstrated in Table 1 . In the given years, liquid assets have $13 \%$, securities have $28 \%$ and loans have $50 \%$ of share in assets on average. The percentage of loans in asset items has risen and the percentage of securities has fallen, especially since 2009. It can be observed that loans have an important share in asset items in recent years.

It will not be a rational action for banks to sell the securities they hold as a response to a contractionary monetary policy. Accordingly, banks are the major borrowers of government bonds and treasury bills. Owing to the fact that interest rates are high as a result of public borrowing in Turkey, it would be a more rational action for banks to reduce loan supply instead of selling high-yield and low-risk government securities (Cengiz, 2007).

For the credit channel to function, not only the banks shares in total finance system but also the total deposits in banks' sources need to be high (Inan, 2001). The fact that the supply of bank loans are affected by the monetary policy actions requires the percentage of deposits in liabilities of banks' balance sheets to be high and the percentage of non-deposit sources to be low. Otherwise, the effects on the asset items may be limited, since there will be compensation for deposits changing as a result of monetary policy actions.

Table 2 demonstrates the percentages of deposit and non-deposit sources in liabilities of banks' balance sheets in Turkey between 2002-2014. In Table 2, it can be observed that the access of banks to non-deposit sources has increased over the years in Turkish banking sector.

Table 2: Percentages of Deposit and Non-Deposit Sources in Turkish Banking Sector

\begin{tabular}{|c|c|c|}
\hline Years & Deposit & Non-Deposit Source \\
\hline $\mathbf{2 0 0 2}$ & 67 & 15 \\
\hline $\mathbf{2 0 0 3}$ & 64 & 16 \\
\hline $\mathbf{2 0 0 4}$ & 64 & 15 \\
\hline $\mathbf{2 0 0 5}$ & 64 & 17 \\
\hline $\mathbf{2 0 0 6}$ & 65 & 18 \\
\hline $\mathbf{2 0 0 7}$ & 64 & 16 \\
\hline $\mathbf{2 0 0 8}$ & 64 & 18 \\
\hline $\mathbf{2 0 0 9}$ & 64 & 17 \\
\hline $\mathbf{2 0 1 0}$ & 61 & 20 \\
\hline
\end{tabular}




\begin{tabular}{|l|l|l|}
\hline $\mathbf{2 0 1 1}$ & 57 & 25 \\
\hline $\mathbf{2 0 1 2}$ & 56 & 23 \\
\hline $\mathbf{2 0 1 3}$ & 54 & 27 \\
\hline $\mathbf{2 0 1 4}$ & 52 & 28 \\
\hline
\end{tabular}

Source: The Banks Association of Turkey.

While total deposit volume was 253.579 million TL in 2005, non-deposit sources were 66.920 million TL; in 2007 total deposit volume was 356.984 million TL and non-deposit sources were 91.614 million TL; in 2009 total deposit volume was 507.258 million TL and non-deposit resources were 137.680 million TL; in 2011 total deposit volume was 656 billion TL and non-deposit sources were 289 billion TL; and in 2014 total deposit volume was 987 billion TL and non-deposit sources increased to 534 billion TL. (BAT, 2006; BAT, 2008; BAT, 2010; BAT, 2012; BAT, 2015). Despite the fact that the development of deposits and non-deposit is considered to weaken that power of monetary policy, it significant that deposits are dominant over non-deposit sources and they have increased just as the non-deposit sources over the years. In general, it is possible to say that monetary policy has the power to affect banks' loan supply for the effectiveness of bank lending channel in Turkey.

For the effectiveness of the credit channel, it is also necessary that borrowers are affected by the changing loan supply. In other words, it is necessary that the production and expenditures must be responsive towards the accessibility of bank loans. For this, bank loans and securities must not be perfect substitutes in the balance sheets of the private sector.

Table 3: Private Sector External Financing Types

\begin{tabular}{|c|c|c|c|c|c|}
\hline Years & $\begin{array}{c}\text { Securities Stocks } \\
\text { (Million TL) }\end{array}$ & $\begin{array}{c}\text { Bank Loans } \\
\text { (Million TL) }\end{array}$ & $\begin{array}{c}\text { Total } \\
\text { (Million TL) }\end{array}$ & $\begin{array}{c}\text { Securities Stocks } \\
\text { (\% Share) }\end{array}$ & $\begin{array}{c}\text { Bank Loans } \\
\text { (\% Share) }\end{array}$ \\
\hline 2002 & 13.176 & 34.215 & 47.391 & 27.8 & 72.2 \\
\hline 2003 & 18.008 & 51.349 & 69.357 & 26.0 & 74.0 \\
\hline 2004 & 25.186 & 79.301 & 104.487 & 24.1 & 75.9 \\
\hline 2005 & 31.929 & 121.762 & 153.691 & 20.8 & 79.2 \\
\hline 2006 & 41.045 & 170.432 & 211.477 & 19.4 & 80.6 \\
\hline 2007 & 52.055 & 216.516 & 268.571 & 19.4 & 80.6 \\
\hline 2008 & 63.859 & 265.629 & 329.488 & 19.4 & 80.6 \\
\hline 2009 & 70.576 & 292.083 & 362.659 & 19.5 & 80.5 \\
\hline 2010 & 83.707 & 421.674 & 505.381 & 16.6 & 83.4 \\
\hline 2011 & 103.898 & 571.022 & 674.920 & 15.4 & 84.6 \\
\hline 2012 & 126.406 & 680.033 & 806.439 & 15.7 & 84.3 \\
\hline 2013 & 142.702 & 912.031 & 1.054 .733 & 13.5 & 86.5 \\
\hline 2014 & 153.020 & 1.093 .269 & 1.246 .289 & 12.3 & 87.7 \\
\hline
\end{tabular}

Source: CMBT (The Capital Market Board of Turkey), CBRT (Central Bank of Republic of Turkey).

Table 3 demonstrates the magnitude and share of security stocks and bank loans for the financial preferences of private sector. As seen in Table 3, the weight of bank loans among the external financing of the firms is quite a lot. Thereby, private sector in Turkey needs the intermediation of banks in order to meet their financing requirements and, accordingly, they are not irresponsive between issuing securities and providing bank loans. In brief, it is possible to say that the private sector in Turkey depends on bank loans to finance their investment projects and, therefore, the changes in loan conditions could be real effects.

\section{LITERATURE REVIEW}

The some studies in the literature that analyze on bank lending channel are presented in appendix part. 


\section{DATA AND METHODOLOGY}

That's why Turkish economy has undergone since 2001 crisis which include the introduction of a flexible exchange rate regime, the recapitalization of the banking sector, and the shift towards an inflation-targeting framework, applying econometric techniques to the pre-crisis period is not very informative about how Turkey's monetary transmission works today (Brooks, 2007). Therefore, the monthly series which were obtained from Central Bank of Republic of Turkey (CBRT) include the period of 2002-2014. The series used in our analysis are presented in Table 4.

Table 4: The Series in VAR Model.

\begin{tabular}{|c|l|}
\hline$P$ & Consumer price index \\
\hline KUR & Real exchange rate \\
\hline SUE & Industrial production index \\
\hline R & Overnight money market interest rate (monetary policy indicator) \\
\hline KRD & Total volume of credit to private sector \\
\hline D & Total volume of deposits \\
\hline MK & Security stocks \\
\hline
\end{tabular}

In the empirical analysis, while total credit (KRD) and security stocks (MK) are used as a representative of asset side of bank's balance sheet, total deposit (D) is used as a liability side of bank's balance sheet. Industrial production index (SUE), consumer price index (P) and real exchange rate (KUR) is used as a representative of economic activity, general price level and open economy respectively. After Bernanke and Blinder (1992) used short term interest rate as a measure of monetary policy shock, most studies in the literature did the same choice. In this regard, the indicator of monetary policy is used overnight money market rate (R) in the empirical analysis.

Industrial production index, total deposits and total credit series were seasonally adjusted using the TramoSeats methodology. All series except for money market interest rate measured in natural logarithms and natural logarithms of $P, K U R, S U E, K R D, D$ and MK were denoted as LP, LKUR, LSUE, LKRD, LD and LMK respectively. Nominal series which are $D, K R D$ and $M K$ converted to real series which were denoted as RD, RKRD and RMK respectively. Eventually the series are represented by LRD, LRKRD, LRMK, LKUR, LSUE, LP, and R.

\section{FINDINGS AND DISCUSSIONS}

\subsection{Unit Root Test}

All variables must be stationary in VAR model. Otherwise, it must be first differenced of the series (Gujarati and Porter, 2012). So, we firstly analyzed stationary properties of the series by employing ADF (Automatic DickeyFuller), PP (Phillips-Perron) and Ng-Perron test in the empirical analysis. The results of unit root tests are presented in Table 5 and in Table 6.

Table 5: ADF and PP Test Results

\begin{tabular}{|c|c|c|}
\hline \multicolumn{3}{|c|}{ ADF Test Results } \\
\hline Series & Level & First Differenced \\
\hline LRD & -2.56 & -12.25 \\
\hline LRKRD & -1.63 & -5.76 \\
\hline LKUR & -3.30 & -9.24 \\
\hline LP & -4.12 & -6.05 \\
\hline LRMK & -2.14 & -9.34 \\
\hline LSUE & -2.63 & -14.34 \\
\hline R & -3.36 & -6.14 \\
\hline \multicolumn{2}{|c|}{ Phillips-Perron Test Results } \\
\hline Series & Level & First Differenced \\
\hline LRD & -2.56 & -12.25 \\
\hline
\end{tabular}




\begin{tabular}{|c|c|c|}
\hline LRKRD & -1.37 & -5.73 \\
\hline LKUR & -2.57 & -8.74 \\
\hline LP & -4.48 & -8.32 \\
\hline LRMK & -1.81 & -9.37 \\
\hline LSUE & -2.63 & -14.32 \\
\hline R & -3.10 & -6.07 \\
\hline \multicolumn{2}{|c|}{ Critical Values (Level) } \\
& $\% 1=-4.01 \% 5=-3.43$ & Critical Values (First Differenced) \\
$\% 1=-3.47 \% 5=-2.88$
\end{tabular}

For ADF and PP tests, the null hypothesis suggests that the series include unit root. For Ng-Peron test, according to $\mathrm{MZ}_{\mathrm{a}}, \mathrm{MZ}_{\mathrm{t}}$ tests the null hypothesis indicates that the series have unit root and according to MSB and MPT tests the null hypothesis indicates that the series are stationary (Ertuğrul and Kenar, 2013).

Table 6: Ng-Perron Test Results

\begin{tabular}{|c|c|c|c|c|}
\hline \multicolumn{5}{|c|}{ Level } \\
\hline Series & MZa & MZt & MSB & MPT \\
\hline LRD & -9.16 & -2.13 & 0.23 & 9.99 \\
\hline LRKRD & -6.36 & -1.73 & 0.27 & 14.33 \\
\hline LKUR & -20.42 & -3.17 & 0.15 & 4.63 \\
\hline LP & -2.26 & -0.94 & 0.41 & 34.56 \\
\hline LRMK & -8.11 & -1.98 & 0.24 & 11.35 \\
\hline LSUE & -6.84 & -1.81 & 0.26 & 13.36 \\
\hline R & -1.21 & -0.58 & 0.48 & 47.92 \\
\hline
\end{tabular}

Ng-Peron critical values the series for MZa, MZt, MSB, MPT respectively; \%1 significance level $-23.80,-3.42,0.14$ and 4,03; \%5 significance level $-17.30,-2.91,0.17$ and 5.48 .

\begin{tabular}{|c|c|c|c|c|}
\hline \multicolumn{4}{|c|}{ First Differenced } \\
\hline Series & MZa & MZt & MSB & MPT \\
\hline LRD & -76.60 & -6.19 & 0.08 & 0.32 \\
\hline LRKRD & -45.03 & -4.74 & 0.10 & 0.55 \\
\hline LKUR & -25.77 & -3.56 & 0.14 & 1.04 \\
\hline LP & -65.21 & -5.70 & 0.09 & 1.43 \\
\hline LRMK & -14.45 & -2.66 & 0.18 & 1.81 \\
\hline LSUE & -76.97 & -6.20 & 0.08 & 0.32 \\
\hline R & -48.38 & -4.89 & 0.10 & 0.56 \\
\hline
\end{tabular}

Ng-Peron critical values the series for MZa, MZt, MSB, MPT respectively; \%1 significance level $-13.80,-2.58,0.17$ and $1.78 ; \% 5$ significance level $-8.10,-1.98,0.23$ and 3.17 .

Table 5 shows that the null hypothesis cannot be rejected for the all series except for LP, that is, all series except for LP are nonstationary in their level forms at $\% 1$ and $\% 5$ levels for both ADF and PP tests, suggesting that all variables except for LP are integrated of order I(1) according both ADF and PP tests. Table 6 shows that the calculated $t$ statistics tested by $\mathrm{MZ}_{\mathrm{a}}$ and $\mathrm{MZ}_{\mathrm{t}}$ for the all series are less and for MSB and MPT tests the calculated $t$ statistics for the all series are greater than the critical values which mean all series are nonstationary in their level forms. For the first difference of series, according to $\mathrm{MZ}_{\mathrm{a}}$ and $\mathrm{MZ}_{\mathrm{t}}$ tests, the calculated $\mathrm{t}$ statistics for the all series are greater and for MSB and MPT tests the calculated t statistics for the all series are less than the critical values at $\% 5$ values, suggesting that the series become stationary after differencing so that the all series are integrated of order I (1) according to Ng-Peron tests. We adopt that all variables are I (1) since $\mathrm{Ng}$-Perron test is a stronger than the other two tests. 


\subsection{Impulse-Response Functions}

Dynamic relations between variable in VAR model were analyzed with impulse-response functions. Responses by other variables in the system to a shock of standard deviation 1 in overnight money market rate representing monetary policy, provides information regarding the effectiveness of bank lending channel. Figure 1 displays the effect of a shock of standard deviation 1 in overnight rate on every other variable.

Figure 1: Variables' response to overnight interest rate shock

Response to Cholesky One S.D. Innovations \pm 2 S.E.

Response of $D(L R D)$ to $D(R)$

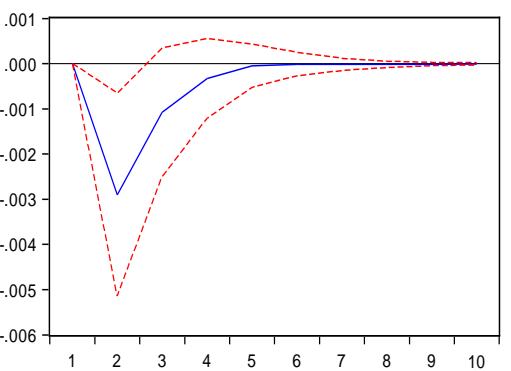

Response of $D(L K U R)$ to $D(R)$

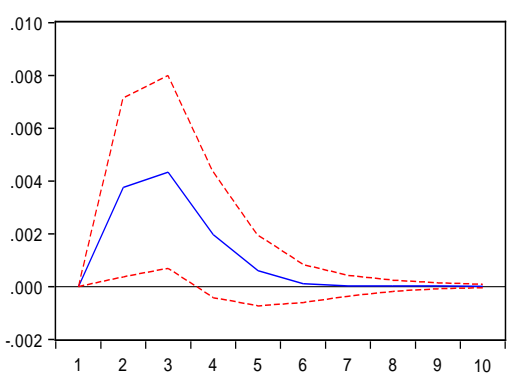

Response of $D(R)$ to $D(R)$

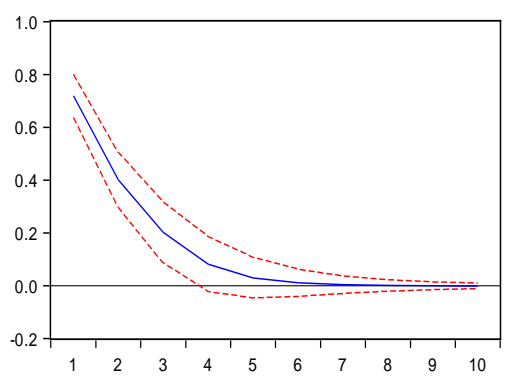

Response of $D(L R K R D)$ to $D(R)$

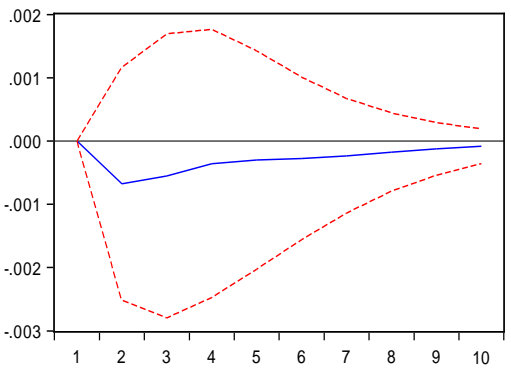

Response of $D(L S U E)$ to $D(R)$

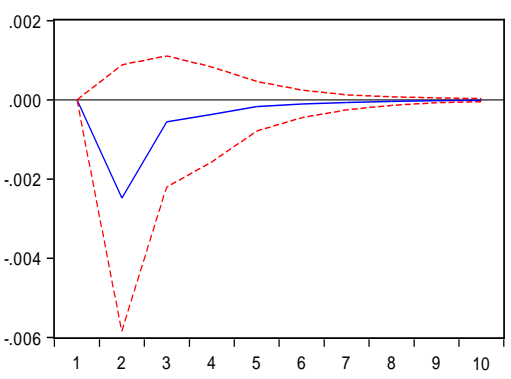

Response of $D(L R M K)$ to $D(R)$

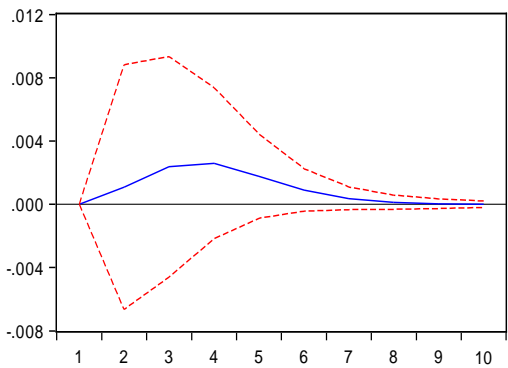

Response of $D(L P)$ to $D(R)$

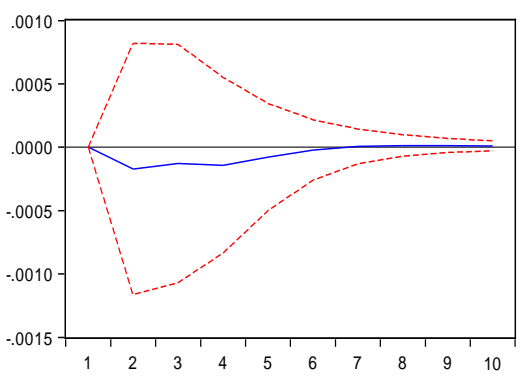

After a positive shock implemented on overnight money market rate (overnight rate), the change in banks' balance sheets is compatible with the process of bank lending channel. In consequence of the shock implemented on money rate it is seen that deposits and loans decrease while securities increase. When faced contractionary monetary policy the decrease in deposits is bigger than the decrease in loans. In Bernanke and Blinder's (1982) study, deposits' faster adjustment process compared to loans is interpreted as; banks can't dry up their loan's supply immediately because contracts regarding bank loans covers a certain period of time. 
In order for loans to play an exclusive role in banks' balance sheets, banks need to reduce their loan's supply rather than selling securities in their portfolios against their decreasing deposits after contractionary monetary policy. Securities' response to overnight rate shock was positive. In other words, after contractionary monetary policy, banks reduced their lending's rather than selling securities they have. This result indicates that loans and securities aren't perfect substitutes and therefore, monetary policy provides the condition of affecting the loan supply. Increase in securities after the monetary shock reversed after nearly 4 months. It is possible to say that as increasing money rates boost the asymmetric information problems after contractionary monetary policy, it is rational for banks to reduce their loan supplies and invest in high-yield securities after the increase in money rates.

In order to analyze the reflection of monetary policy to real economy, response of industrial production index against the monetary shock was examined. As one can see from the impulse-response functions, response of industrial production index against the positive money rate was powerful and negative. The simultaneous movement of bank loans and industrial production index against the monetary shock indicate that the borrowers are bank-dependent. However, it is seen that the response of industrial production to the monetary shock reversed after 2 months and it died down after 6 months. After the money rate shock, prices initially decreased and then they were fixed until they started to rise after 4 months and after 6 months they were close to zero. After the positive shock implemented on interest rates, real exchange rate initially increased and after 3 months it decreased. In other words, after the contractionary monetary policy, domestic currency started to increase after 3 months. Accordingly it's possible to say that determining of exchange rate could be other factor (such as international developments, expectations) in Turkish economy.

\section{CONCLUSION}

According to credit view, banks play a special role in economy as banks are experts at solving asymmetric information problems in financial system. Influence of monetary policy actions on loan supply affects the expenditure of households and firms who are ineligible for direct access to capital markets. In this study, the effectiveness of bank lending channel for Turkish economy was analyzed by using VAR method with monthly data covering the period from 2002 to 2014. Before making the empirical analysis, it had been confirmed that required conditions for bank lending channel to operate were provided to a considerable extent for Turkish economy.

According to empirical analysis results based on impulse-response functions, bank credit channel is operating in Turkish economy. There was a decrease in bank loans because of a positive shock implemented on overnight money market rate. In other words, banks responded to the decrease in deposits against contractionary monetary policy, by reducing the loans instead of selling the securities in their portfolios. The response of industrial production index to the shock implemented on money rates was examined in order to assess the influence of monetary policy on real economic activity.

The response of industrial production index to the monetary policy shock was simultaneous, powerful and negative. However, it was assessed that this response occurred in a short term. This situation supports the idea that, monetary policy is effective in short term but is neutral in long term. In other words, the effect of the monetary policy shock on banks loans is reflected on the short-term economic activity. In parallel with the result of Cengiz's (2007) studies, it was discovered that monetary policy affects real economy in short term, however, in contrast to the studies in literature, the effect of monetary policy shock on exchange rates was initially positive. Initial decrease of the prices in response to the interest shock reveals that it is appropriate for monetary policy to use short-term interest rates in maintaining the price stability. Results obtained from the studies indicate that the monetary policy affects bank loans and this effect has important results regarding real economy in short term. Analysis results suggest that bank lending channel is an effective channel in monetary transmission mechanism for Turkish economy. 


\section{REFERENCES}

Aban, M. J. A. C. (2013). "Transmission of monetary policy through the bank lending channel in the Philippines". International Journal of Trade, Economics and Finance, 4(1), 37-42.

Aklan, N. A. ve Nargeleçekenler, M. (2008b). "Para politikalarının banka kredi kanalı üzerine etkileri”. İstanbul Üniversitesi Siyasal Bilgiler Fakültesi Dergisi, 39, 109-132.

Bernanke, B. S. (1993). “Credit in the macroeconomy”. Federal Reserve Bank of New York Quarterly Review, 18, 50-70.

Bernanke, B. S. and Gertler, M. (1995). "Inside the black box: the credit channel of monetary policy transmission". National Bureau of Economic Research (NBER) Working Paper Series, 5146, 1-38.

Benkovskis, K. (2008). "Is there a bank lending channel of monetary policy in Latvia? Evidence from bank level data". Latvijas Banka, Working paper, 1-45.

Bernanke, B. S. and Blinder, A. S. (1992).The federal funds rate and the channels of monetary transmission. The American Economic Review, 82 (4), 901-921.

Cecchetti, S. G. (1995). “Distinguishing theories of the monetary transmission mechanism”. Federal Reserve Bank of St. Louis Review, 8397.

Cecchetti, S. G. (1999). "Legal structure, financial structure, and the monetary policy transmission mechanism". Federal Reserve Bank of New York Economic Policy Review, 5 (2), 9-28.

Cengiz, V. (2007). “Parasal aktarım mekanizmasında kredi kanalının etkinliği üzerine bir analiz: Türkiye örneği (1990-2006)”. PhD Thesis, Kocaeli University.

Claus, I. and Grimes, A. (2003). "Asymmetric information, financial intermediation and the monetary transmission mechanism: a critical review". New Zealand Treasury Working Paper, 03(19), 1-24.

Çavuşoğlu, T. (2002). “Credit transmission mechanism in Turkey: an empirical investigation”. Economic Research Center (ERC) Working Papers in Economics, 1-30.

De Bondt, G. J. (1998)." Financial structure: theories and stylized facts for six EU countries”. De Economist, 146 (2), $271-301$.

Erdoğan, S. ve Beşballı, S. G. (2009). "Türkiye'de banka kredileri kanalının işleyişi üzerine ampirik bir analiz". Doğuş Üniversitesi Dergisi, $11(1), 28-41$.

Ertuğrul, H. M. ve Kenar, A. (2013). "External Debt and GDP Relationship: A Dynamic Analysis For Turkey”. Trakya Üniversitesi Iktisadi ve İari Bilimler Fakültesi E-Dergi, 2(1), 78-94.

Gambacorta, L. ve Rossi, C. (2010). “Modelling bank lending in the euro area: a nonlinear approach". Applied Financial Economics, 20, 1099-1112.

Gómez-González, J ve Grosz, F. (2007). “Evidence of a bank lending channel for Argentina and Colombia”.Cuadernos De Economia, 44, 109126.

Gujarati, D. N. ve Porter, D. C. (2012). “Temel Ekonometri”. (Çev: Ü. Şenesenve G. G. Şenesen). İstanbul: Literatür Yayıncılık.

Holtemöller, O. (2002). "Identifying a credit channel of monetary policy transmission and empirical evidence for Germany".1-19.

http://www.eea-esem.com/papers/eea-esem/eea2002/841/Crch-ger.pdf

Inan, E. A. (2001). “Parasal aktarım mekanizmasının kredi kanalı ve Türkiye”. Türkiye Bankalar Birliği Bankacılar Dergisi, (39), 3-19.

Jimborean, R. (2009). "The role of banks in the monetary policy transmission in the new EU member states". Economic Systems, 33, 360375 .

Juks, R. (2004). "The importance of the bank-lending channel in Estonia: evidence from micro-economic data". Working Papers of Eesti Pank, (6), 1-38.

Kashyap, A. K., Stein, J. C. and Wilcox, D. W. (1992). "Monetary policy and credit conditions: evidence from the composition of external finance". National Bureau of Economic Research (NBER) Working Paper Series, 4015,1-36.

Kashyap, A. K. and Stein, J. C. (1994). “Monetary policy and the bank lending”. The University of Chicago Press, 221-261.

Leroy, A. (2014). "Competition and the bank lending channel in Eurozone". Journal of International Financial Markets, Institutions \& Money, 31, 296-314.

Mishkin, F. S. (2010). "The economics of money, banking and financial markets" (9th edition). Boston: Pearson, Global Edition.

Oliner, S. D. and Rudebusch, G. D. (1995). "Is there a bank lending channel for monetary Policy". Federal Reserve Bank of San Francisco, Economic Review, (2), 3-20. 
Oliner, S. D. and Rudebusch, G. D. (1996b). "Is there a broad credit channel for monetary policy". Federal Reserve Bank of San Francisco, Economic Review, (1), 3-13.

Özşuca, E. A. ve Akbostancı, E. (2012). "An empirical analysis of the bank lending channel in Turkey”. íktisat, i̇şletme ve Finans, 28 (328), $33-$ 50.

Saumitra, B. and Toto, G. (2012). "The bank lending channel of monetary policy transmission: evidence from an emerging market, India". Munich Personel Repec Archieve, 1-27.

CMBT (2004). "2004 Yılı Faaliyet Raporu”. Capital Markets Board of Turkey.

CMBT (2013). "2013 Yılı Faaliyet Raporu". Capital Markets Board of Turkey.

Sun, L., Ford, J. L. and Dickinson D. G. (2010). "Bank loans and the effects of monetary policy in China: VAR/VECM approach". China Economic Review, 21, 65-97.

Thornton, D. L. (1994). "Financial innovation deregulation and the "credit view" of monetary policy". Federal Reserve Bank of St. Louis Review, 31-49.

BAT (2004). "Banks in Turkey 2003". The Bank Association of Turkey.

BAT (2006). "Banks in Turkey 2005". The Bank Association of Turkey.

BAT (2008). "Banks in Turkey 2007". The Bank Association of Turkey.

BAT (2010). “Banks in Turkey 2009". The Bank Association of Turkey.

BAT (2012). "Banks in Turkey 2011". The Bank Association of Turkey.

BAT (2014). “Banks in Turkey 2013”. The Bank Association of Turkey.

BAT (2015). "Banks in Turkey 2014". The Bank Association of Turkey.

Yalán, C. C. (2010). "The bank lending channel in Peru: evidence and transmission mechanism". Banco Central de Reserva del Perú, Working Paper Series. 2010-021, 1-39.

https://www.hazine.gov.tr/tr-TR/Istatistik-Sunum-Sayfasi?mid=249\&cid=26

http://www.spk.gov.tr/apps/aylikbulten/index.aspx?submenuheader=-1

http://evds.tcmb.gov.tr/ 
APPENDIX - Bank Loans Channel Literature Summary

\begin{tabular}{|c|c|c|c|c|}
\hline $\begin{array}{l}\text { Researcher / } \\
\text { Date of } \\
\text { Publication }\end{array}$ & The Country & The Period & $\begin{array}{l}\text { The } \\
\text { Method }\end{array}$ & Obtained Results \\
\hline $\begin{array}{l}\text { Bernanke and } \\
\text { Blinder (1992) }\end{array}$ & USA & 1959-1989 & VAR & $\begin{array}{l}\text {-The decrease in deposits after the reducer monetary } \\
\text { policy reflects on the loans with delay. } \\
\text { - Bank loans and unemployment rate act jointly after a } \\
\text { change in federal funds rate. Therefore, bank loans are } \\
\text { an important component of monetary transmission. }\end{array}$ \\
\hline De Bondt (1998) & $\begin{array}{c}6 \text { European } \\
\text { Countries }\end{array}$ & 1990-1995 & $\begin{array}{l}\text { Panel } \\
\text { Data }\end{array}$ & $\begin{array}{l}\text { It has been determined that while Germany, Belgium } \\
\text { and The Netherlands have solid bank lending channels, } \\
\text { the banks face a liquidity limitation in Italy and France } \\
\text { and the bank lending channel is not effective in England. }\end{array}$ \\
\hline $\begin{array}{l}\text { Holtemöller } \\
\text { (2002) }\end{array}$ & Germany & $1975-1998$ & VAR & $\begin{array}{l}\text { As a consequence of strict monetary policy, the increase } \\
\text { in short-term interest rates raises external financing } \\
\text { premiums and this causes a weak negative effect on } \\
\text { inflation and strong negative effect on production and, } \\
\text { therefore, bank lending channel is effective. }\end{array}$ \\
\hline $\begin{array}{l}\text { Gambacorta and } \\
\text { Rossi (2010) }\end{array}$ & Euro Zone & $1985-2005$ & AVECM & $\begin{array}{l}\text { It has been determined that contractionary monetary } \\
\text { policy has a greater effect on bank lending, prices and } \\
\text { real output than expansionary monetary policy. }\end{array}$ \\
\hline Leroy (2014) & Euro Zone & $1999-2011$ & GMM & $\begin{array}{l}\text { Findings to prove the existence of bank credit channel } \\
\text { have been obtained. It has been determined that capital } \\
\text { value, liquidity level and magnitude of the banks affect } \\
\text { the bank lending channel. Lerner index has been used to } \\
\text { measure market power of the banks and it has been } \\
\text { proved that banks with higher market power are less } \\
\text { sensitive to the monetary policy. Also, it has been stated } \\
\text { in the study that the increasing competition boosts the } \\
\text { efficiency of monetary policy transmission through bank } \\
\text { lending channel. }\end{array}$ \\
\hline $\begin{array}{l}\text { Gómez-González } \\
\text { and Grosz (2007) }\end{array}$ & $\begin{array}{l}\text { Colombia } \\
\text { and } \\
\text { Argentina }\end{array}$ & $\begin{array}{l}\text { 1995:1- } \\
\text { 2005:9 } \\
\text { (Colombia) } \\
\text { 2003:08- } \\
\text { 2005:11 } \\
\text { (Argentina) }\end{array}$ & $\begin{array}{l}\text { Panel } \\
\text { Data }\end{array}$ & $\begin{array}{l}\text { It has been determined that interbank overnight interest } \\
\text { rate in Argentina cannot directly affect the total loan } \\
\text { growth rate, along with that, the monetary policies in } \\
\text { both countries affect the loan supply by changing capital } \\
\text { adequacies and liquidities of banks. Therefore, it has } \\
\text { been concluded that bank lending channels are effective } \\
\text { in both countries }\end{array}$ \\
\hline $\begin{array}{l}\text { Sun, Ford and } \\
\text { Dickinson (2010) }\end{array}$ & China & $1996-2006$ & VAR/VEC & $\begin{array}{l}\text { It has been determined that monetary policy affects } \\
\text { macroeconomic activities through bank loans and, } \\
\text { therefore, bank loans play an important role through } \\
\text { which monetary policy affects real economy. }\end{array}$ \\
\hline $\begin{array}{l}\text { Saumitra and } \\
\text { Toto (2012) }\end{array}$ & India & $1996-2007$ & $\begin{array}{l}\text { Dynamic } \\
\text { Panel } \\
\text { Data }\end{array}$ & $\begin{array}{l}\text { In this study where an effective bank credit channel has } \\
\text { been determined, it has been concluded that small- } \\
\text { scale, illiquid banks are more responsive to monetary } \\
\text { policy changes. Besides, it has been found that public } \\
\text { banks are more responsive to monetary policy than } \\
\text { foreign banks. }\end{array}$ \\
\hline Aban (2013) & Philippines & $2008-2011$ & OLS & $\begin{array}{l}\text { It has been proved that the magnitude factor of the bank } \\
\text { is a factor that affects the existence the bank lending } \\
\text { channel and loans of small-scale banks are more } \\
\text { responsive to monetary shocks. }\end{array}$ \\
\hline Yalán (2010) & Peru & $2001-2010$ & $\begin{array}{l}\text { VAR, } \\
\text { SVAR }\end{array}$ & $\begin{array}{l}\text { It has been concluded in the study that bank lending } \\
\text { channel operates in Peru but this channel is not } \\
\text { important in the process of transmission of monetary } \\
\text { policy into macroeconomic variables. }\end{array}$ \\
\hline
\end{tabular}




\begin{tabular}{|c|c|c|c|c|}
\hline Çavuşoğlu (2002) & Turkey & 1988-1999 & $\begin{array}{l}\text { Dynamic } \\
\text { Panel } \\
\text { Data }\end{array}$ & $\begin{array}{l}\text { Based on the fact that there is not an important relation } \\
\text { between the change in monetary policy indicator and } \\
\text { real growth of loan supply, it has been concluded that } \\
\text { bank credit channels do not function. }\end{array}$ \\
\hline $\begin{array}{l}\text { Aklan and } \\
\text { Nargeleçekenler } \\
\text { (2008b) }\end{array}$ & Turkey & $1988-2001$ & $\begin{array}{l}\text { Panel } \\
\text { Data }\end{array}$ & $\begin{array}{l}\text {-The effects of monetary policy on bank loan supply vary } \\
\text { depending on the liquidity degree of the banks. } \\
\text {-Banks with low liquidity degree are more responsive to } \\
\text { the monetary policy changes than the banks with high } \\
\text { liquidity degree. The researches interpret the obtained } \\
\text { findings as a proof that bank lending channel does not } \\
\text { function effectively. }\end{array}$ \\
\hline $\begin{array}{l}\text { Erdoğan and } \\
\text { Beşballı (2009) }\end{array}$ & Turkey & 1996-2006 & VAR & $\begin{array}{l}\text {-That loans decreased more than securities after a } \\
\text { monetary shock has been interpreted as an indicator of } \\
\text { banks conducting loan rationing. } \\
\text {-Based on the fact that loans and industrial production } \\
\text { index move in the same direction, it has been found that } \\
\text { firms are dependent on bank loans and bank lending } \\
\text { channel operates effectively. }\end{array}$ \\
\hline $\begin{array}{c}\text { Özşuca and } \\
\text { Akbostancı (2013) }\end{array}$ & Turkey & $1988-2009$ & $\begin{array}{l}\text { Dynamic } \\
\text { Panel } \\
\text { Data }\end{array}$ & $\begin{array}{l}\text { It has been determined that there was an effective bank } \\
\text { credit channel between 1988-2001, however the } \\
\text { efficiency of bank credit channel has been much greater } \\
\text { after the crisis. }\end{array}$ \\
\hline
\end{tabular}

